\title{
URGENSI PERLINDUNGAN HUKUM TERHADAP PENGGUNA JASA MOTORCYCLE TAXI PERSPEKTIF HUKUM PERLINDUNGAN KONSUMEN DAN TEORI MASHLAHAH
}

\author{
Musataklima \\ Fakultas Syariah \\ Universitas Islam Negeri Maulana Malik Ibrahim Malang \\ Email: musataklima20@gmail.com
}

\section{Abstract}

Transportation gets a central position for the sustainability of business concerning people movement from one place to another. In certain areas, transportation is not monopolized by public modes. The non-public ones are also turned into public transportation, such as motorbikes, known as ojek (motorcycle taxis). This research describes the review of mashlahab and the urgency of consumer legal protection in using motorcycle taxi. This is a normative juridical study with a doctrinal approach relying on secondary data consisting of primary, secondary, and tertiary legal material obtained through literature studies. Those data are analyzed using descriptive analysis methods. The results of the study are: first, using motorcycle taxis contains the values of maslahah (benefit), in terms of daruriyah, hajjiyah, and tabsiniyah domains in fulfilling the community needs; second, because of its mashlahah values, the users (passengers) need to have legal protection by providing legal certainty for motorcycle taxi. It could be done through revising the 2009 Law Number 22.

Angkutan mendudukiposisi yang sentral bagikeberlangsungan dalam keberangsungan bisnis proses perpindahan orang dari satu tempat ke tempat lain. Di daerah-daerah tertentu, angkutan tidak dimonopoli moda angkutan umum, moda angkutan yang bukan umum pun dijadikan moda angkutan umum, seperti angkutan dengan sepeda motor yang dikenal dengan ojek atau motorcycle taxi. Penelitian memiliki tujuan untuk mendeskripsikan tinjauan mashlahah dan urgensitas perlindungan hukum terhadap konsumen angkutan orang dengan motorcycle taxi. Penelitian ini adalah 
penelitian yuridis normatif dengan pendekatan doktrinal yang bertumpu kepada sumber data sekunder yang terdiri dari bahan hukum primer, sekunder dan tersier yang didapat melalui studi pustaka, dan dianalisis dengan menggunakan metode deskriptif analisis. Hasil penelitian, pertama, angkutan orang dengan motorcyle taxi (ojek) mengandung nilai-nilai kemaslahatan, baik pada ranah daruriyah, hajjiyah maupun tahsiniyah dalam memenubi kebutuhan masyarakat. Kedua, oleh karena terdapat nilai-nilai mashlahah, maka pengguna jasanya urgen untuk diberi perlindungan hukum dengan cara memberikan kepastian bukum legalitas motorcyle taxi dengan cara melalui revisi Undang-Undang No. 22 Tabun 2009.

Keywords: consumer, legal protection, mashlahah, motorcycle taxi

\section{Pendahuluan}

Angkutan atau transportasi dewasa ini merupakan jantung bagi keberlangsungan hidup manusia, kehidupan manusia akan mengalami kelumpuhan jika moda-moda angkutan tidak diusakan keberadaannya, hal ini sudah menjadi fakta yang tidak terbantahkan.

Dalam perspektif bisnis, angkutan juga menduduki posisi yang sentral bagi keberlangsungan lalu lintas/ distribusi logistik/ barang dan jasa, tanpanya maka keberlangsungan bisnis akan terganggu kalau tidak bisa dikatakan akan mengalami kelumpuhan secara totalitas. ${ }^{1}$

Indonesia sebagai negara hukum berkewajiban memberikan fondasi yuridis bagi setiap tindak tanduk umat manusia sebagai menifestasi dari eksistensi negara hukum yang dianutnya. Oleh karena itu sebagai fondasi yuridis bagi aktivitas pengangkutan ini, maka lahirlah beberapa peraturan perundang-undangan. Undang-Undang No. 22 Tahun 2009 tentang Lalu Lintas dan Angkutan Jalan, Undang-Undang No. 1 Tahun 2009 tentang Penerbangan, Undang-Undang No. 23 Tahun 2007 tentang Kereta Api, Undang-Undang No. 18 Tahun 2008 tentang Pelayaran.

Dasar hukum keberadaan angkutan darat melalui jalan umum adalah UndangUndang No. 22 Tahun 2009 tentang Lalu Lintas dan Angkutan jalan. Dalam Pasal 138 Undang-Undang No. 22 Tahun 2009 disebutkan bahwa "Angkutan umum orang dan/atau barang hanya dilakukan dengan Kendaraan Bermotor Umum". Kendaraan Bermotor Umum adalah setiap Kendaraan yang digunakan untuk angkutan barang dan/atau orang dengan dipungut bayaran. ${ }^{2}$

1 Abdul Kadir Muhammad, Hukum Pengangkutan Niaga (Bandung: PT Citra Aditya Bakti, 2008), h. 33-36.

2 Pasal 1 Undang-Undang No. 22 tahun 2009 tentang Lalu Lintas dan Angkutan Jalan 
Berangkat dari pasal di atas, maka dapat dipahami bahwa angkutan orang dengan sepeda motor yang bukan merupakan kendaraan umum adalah terlarang di negeri ini, namun perlu diketahui bahwa dalam kehidupan masyarakat baik yang berbasis tradisionalitas maupun modernitas, terdapat fakta yang yang menunjukkan eksistensi angkutan orang dengan sepeda motor. Hal ini bisa kita lihat disekeliling kita, baik dalam kehidupan pedesaan maupun perkotaan. Bisa dilihat dipangkalan ojek yang ada diterminal-terminal dan pasar-pasar tradisional, khusus di daerah-daerah pedesaan, angkutan orang dengan menggunakan sepeda motor merupakan angkutan utama masyarakat, hal ini terjadi seperti di Pulau Kangean Sumenep Madura.

Dalam angkutan orang dengan sepeda motor ini, terdapat dua pihak yang yang terlibat secara langsung, yaitu pengemudi dan konsumen. Konsumen adalah adalah setiap orang pemakai barang dan/atau jasa yang tersedia dalam masyarakat, baik bagi kepentingan diri sendiri, keluarga, orang lain maupun makhluk hidup lain dan tidak untuk diperdagangkan. ${ }^{3}$ Dengan dilarangnya angkutan orang dengan menggunakan sepeda motor, maka konsumen dalam konteks ini tidak mendapat perlindungan hukum walaupun keduanya sudah terjadi perjanjian.

Pemerintah sebagai pihak yang bertanggung jawab atas pembinaan penyelenggaraan perlindungan konsumen untuk menjamin diperolehnya hak konsumen dan pelaku usaha serta dilaksanakannya kewajiban konsumen dan pelaku usaha. ${ }^{4}$ Perlu mengusahakan kebijakan yang mengarah kepada perlindungan konsumen angkutan orang dengan sepda motor. Dalam Islam terdapat kaidah

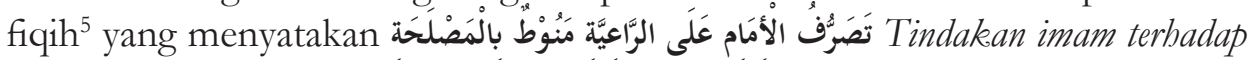
rakyatnya harus dikeaitkan dengan kemasláhatan.

Berangkat dari kewajiban pemerintah di atas dan fakta angkutan orang dengan sepeda motor di atas yang masih dalam proses menjadi, maka perlu diteliti terkait dengan urgensi tidaknya pelindungan konsumen pada angkutan orang dengan sepeda motor. Selain itu perlu juga dikaji maslahat dan mafsadat dari angkutan orang dengan sepeda motor. Maslahat dan mafsadat langkah awal dalam menapaki urgensi perlindungan hukum bagi konsumennya. Berdasarkan ini maka penelitian terkait dengannya penting untuk dilakukan.

3 Pasal 1 Undang-Undang No. 8 Tahun 1999 tentang Perlindungan Konsumen

4 Pasal 29 Undang-Undang No. 8 Tahun 1999 tentang Perlindungan Konsumen

5 Ali Ahmad An-Nadwiy, القو اعد الفقهية مفهومها ونشأتها وتطور ها ودر اسة مؤلفاتها أدلتها مهنها تطبيقاتها (Damaskus: Darul Kalam, 1994), h. 171, 157 dan 96. As-Suyuthi, Al-Asybah Wa An-Nadzair, (alMaktabah as-Syamila), h. 233. 
Metode Penelitian

Penelitian ini merupakan jenis penelitian pustaka (normatif), ${ }^{6}$ dengan pendekatan yang digunakan dalam penelitian ini adalah pendekatan perundangundangan (statute approach). Pendekatan perundang-undangan digunakan dengan tujuan untuk menelaah undang-undang dan regulasi yang berkaitan dengan isu yang sedang diteliti, yang bertumpu kepada keada sumber data sekunder yang terdiri dari bahan hukum primer, bahan hukum sekunder dan bahan hukum tersier, ${ }^{7}$ yang memiliki kaitan erat dengan obyek penelitian.

Bahan hokum primer yang digunakan dalam penelitian ini terdiri dari Undang-undang Dasar 1945, Undang-Undang Republik Indonesia Nomor 8 Tahun 1999 tentang Perlindungan Konsumen. Undang-Undang Nomor 22 Tahun 2009 tentang Lalu Lintas dan Angkutan Jalan Pendapat Ulama tentang Mashlahah, Bahan Hukum Sekunder, ialah bahan hukum yang memberikan penjelasan mengenai bahan hukum primer, antara lain berupa tulisan-tulisan dari para pakar yang berhubungan dengan masalah yang diteliti ataupun yang berkaitan dengan bahan hukum primer, meliputi literatur-literatur berupa buku-buku, makalah atau bahan-bahan seminar, majalah-majalah, jurnal, dan tulisan-tulisan ilmiah yang ada sangkut pautnya dengan penelitian ini. Bahan hukum tersier, yakni bahan yang memberikan petunjuk maupun penjelasan terhadap bahan hukum primer dan sekunder. Bahan hukum tersier yang digunakan dalam penelitian hukum ini adalah kamus.

Bahan-bahan hokum di atas dikumpulkan studi dokumen atau studi bahan pustaka, ${ }^{8}$ yang dianalisis secara deksriptif kualitatif, yaitu setelah data terkumpul kemudian dituangkan dalam bentuk uraian logis dan sistematis, selanjutnya dianalisis untuk memperoleh kejelasan penyelesaian masalah, kemudian ditarik kesimpulan secara deduktif, yaitu dari hal yang bersifa umum menuju hal yang berisifat khusus. ${ }^{9}$ Jadi metode analisis yang digunakan dalam penelitian ini adalah deskriptif analisis yaitu apa yang dinyatakan oleh responden secara tertulis atau lisan dan juga perilakunya yang nyata, diteliti dan di pelajari sebagai sesuatu yang utuh. ${ }^{10}$

6 Cholid Narbuko dan Abu Achmadi, Metodologi Penelitian, (Jakarta: Bumi Aksara, 2005), h. 41.

7 Soerjono Soekanto dan Sri Mamudji, Penelitian Hukum Normatif Suatu Tinjauan Singkat, ed. Kesembilan, (Jakarta: PT.Raja Grafindo Persada, 2006), h. 13

8 Soerjono Soekanto, Pengantar Penelitian Hukum, (Jakarta Universitas Indonesia Press, 1986), h. 66

9 Soetrisno Hadi, Metodologi Reseacrh Jilid II, (Yogyakarta: Yayasan Penerbit Fakultas Psikologi UGM, 1985), h. 10

10 Soerjono Soekanto, Pengantar Penelitian, (Jakarta : UI Press, 1986), h. 12 


\section{Pembahasan}

\section{Tinjauan Teori Mashlahah Terhadap Aktivitas Angkutan Orang dengan Menggunakan Motorcycle Taxi}

Angkutan Orang dengan Menggunakan Sepeda Motor (Motocycle Taxi) sering disebut ojek. Kata "ojek" adalah sebuah kata yang lumrah di telinga masyarakat Indonesia. Bahkan Robert Cervero, seorang peneliti dari Perserikatan BangsaBangsa (PBB) tidak menggunakan istilah yang lebih dikenal yaitu motocycle taxi tetapi juga menggunakan kata "ojeks" dan menggolongkannya ke dalam alat transportasi dan angkutan informal di Indonesia. ${ }^{11}$

Wikipedia Bahasa Indonesia mendefinisikan juga ojek sebagai "transportasi umum informal di Indonesia yang berupa sepeda motor atau sepeda, namun lebih lazim sebagai sepeda motor". ${ }^{12}$ Sedangkan dalam Kamus Bahasa Indonesia, ojek diartikan sebagai " sepeda atau sepeda motor yang ditambangkan dengan cara memboncengkan penumpang atau penyewanya". ${ }^{13}$

Dapat dikatakan bahwa ojek muncul dari kearifan lokal karena ojek melihat peluang untuk meningkatkan taraf hidupnya tanpa didesak atau diajari pihak manapun. ${ }^{14}$ Setidaknya ada empat alasan munculnya ojek: ${ }^{15}$ (1) Jumlah angkutan umum yang terbatas. (2) Pelayanan angkutan umum yang buruk karena menolak penumpang yang membawa banyak barang bawaan. (3) Angkutan umum tidak dapat menjangkau tempat-tempat tertentu sesuai keinginan calon penumpang. (4) ojek adalah lapangan kerja alternatif (di bidang angkutan)

Agus Sarwo Edi S. dalam penelitiannya menunjukkan bahwa ojek adalah angkutan yang mampu mengantar penumpang atau barang dengan cepat. ${ }^{16}$ Peneliti lain, Anwar, mengatakan bahwa ojek sangat dibutuhkan di daerah yang belum terjangkau sarana transportasi formal karena sifatnya yang fleksibel, efektif dan efisien serta memiliki jangkauan waktu operasi yang tidak terikat. ${ }^{17}$ Sedangkan

11 Robert Cervero, Informal Transport in the Developing World (Nairobi: United Nations for Human Settlements, tth), h. 94.

12 https:/ /id.wikipedia.org/w/index.php? search=ojek\&title=Istimewa:Pencarian\&fulltext=

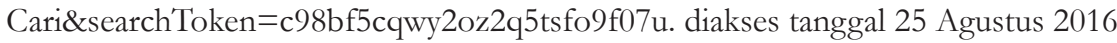

13 http://kbbi.web.id/ojek, diakses tanggal 27 Mei 2016 Jam 12. 48 WIB

14 Marcus J. Pattinama, "Pengentasan Kemiskinan dengan Kearifan local (Studi Kasus di Pulau Buru-Maluku dan Surade Jawa Barat). Makara, Sosial Humaniora, Vol. 13 No. 1 (Juli 2009), h. 1 .

15 Firman Shantyabudi, "Tukang Ojek dan Interaksi Sosial” (Jakarta: Universitas Indonesia, 2003), h. 44.

16 Agus Sarwo Edi S., "Karakter Pengoperasian Angkutan Ojek Sebagai Sarana Angkutan di Kota Gubug" (Semarang: Universitas Diponegoro, 2005), h. ii.

17 Anwar. Analisa Kinerja Ojek, Jurnal Sains dan Inovasi, Vol. 5 No. 2 Tahun 2009, h. 126. 
Djoko Setijowarno dan Yovita Indrayati mengatakan bahwa ojek adalah angkutan umum yang lebih cepat dan fleksibel dibandingkan dengan angkutan umum lainnya karena menggunakan tekhnologi sederhana, investasi murah, cara pengoperasian yang sederhana, perawatan mudah dan daya jelajah medan yang tinggi. ${ }^{18}$

Berdasarkan hasil pengamatan lapangan, dibeberapa daerah, misal di Pulau Kangean, ojek juga berperan membuka isolasi terhadap wilayah-wilayah yang relatif tertutup. Biasanya dengan cara merintis jalan dari dan ke tempat-tempat yang tidak memiliki akses jalan umum untuk mengantar dan menjemput penumpang. Jalan yang dirintis oleh para tukang ojek inilah yang kemudian digunakan oleh para pengendara sepeda motor lainnya, bahkan diperluas agar dapat dilalui oleh kendaraan yang lebih besar sehingga berkembang menjadi jalan raya. Jadi dalam hal ini para tukang ojek sangat berperan dalam membuka akses jalan kepada wilayah-wilayah yang terisolir. Inilah kontribusi yang diberikan oleh para tukang ojek baik kepada pengusaha, penguasa maupun masyarakat umum.

Selain di Indonesia, Ojek (Inggirs: motorcycle taxi) dikenal beberapa negara lain seperti Thailand, Kamboja, India, Swedia, Inggris dan Amerika Serikat, bahkan juga negara-negara di benua Afrika seperti Nigeria dan Afrika Selatan. ${ }^{19}$ Di Thailand ojek merupakan salah satu sarana angkutan umum penumpang yang resmi. Bahkan Thailand merupakan negara pertama di dunia yang melegalkan ojek sebagai angkutan umum. ${ }^{20} \mathrm{Hal}$ serupa juga ada di Kamboja. Bagi masyarakat setempat ojek adalah alat transportasi umum yang utama. Tukang ojek di Kamboja disebut motodups. ${ }^{21}$

Keberadaan ojek di beberapa negara di atas dilindungi oleh undangundang, atau setidak-tidaknya keberadaannya diatur oleh pemerintah. Dengan demikian ojek dan penumpangnya mendapat perlindungan, kenyamanan dan jaminan keselamatan. Itulah sebabnya wikipedia mendefinisikan ojek sebagai "a licensed form of transport in some countries" $\mathrm{Hal}$ ini tentunya berbeda dengan di Indonesia, walau secara factual hampir di seluruh pelosok Indonesia ada aktivitas pengangkutan dengan motorcycle taxi (ojek), namun keberadaannya belum diakui.

18 Djoko Setijowarno dan Yovita Indrayati, "Peningkatan Peran Ojek sebagai Salah Satu Alternatif Angkutan". Referensi Ilmiah Indonesia (2010), h. iii.

19 http://en.wikipedia.org/wiki/Talk:Motorcyle_taxi.htm, diunduh pada 18 Mei 2016, pukul 22.03 WIB.

20 Ryosuke Oshima dkk. Study on Regulation of Motorcycle Taxi Service in Bangkok, Journal of the Eastern Asia Society for Transportation Studies, Vol. 7 Tahun 2007, h. 1828.

21 Ryosuke Oshima dkk. Study on Regulation of Motorcycle Taxi Service in Bangkok, h. 1828.

22 Ryosuke Oshima dkk. Study on Regulation of Motorcycle Taxi Service in Bangkok, h. 1828. 
Merujuk diskusi di atas, dapat diketahui kehadiran motorcycle taxi di Indonesia dengan beberapa latar belakang yang melingkupinya, yaitu: (1) Jumlah angkutan umum yang terbatas. (2) Pelayanan angkutan umum yang buruk karena menolak penumpang yang membawa banyak barang bawaan. (3) Angkutan umum tidak dapat menjangkau tempat-tempat tertentu sesuai keinginan calon penumpang. (4) Tukang ojek adalah lapangan kerja alternatif (di bidang angkutan)

Adapun manfaat kehadiran motorcycle taxi ditengah-tengah kehidupan masyarakat, yaitu: (1) Jauh lebih murah dibanding apabila anda menggunakan Taksi mobil, (2) Jauh lebih cepat dibanding apabila menggunakan jasa becak, dan (3) Jauh lebih cepat harus menunggu angkutan bis kota yang terikat jadwal. (4) Ongkos Pasti hemat. Menghindari tawar-menawar yang membosankan dan terkadang membuat anda membayar lebih mahal apabila menggunkan jasa ojek konvensional. (5) Perjalanan Lancar, tidak terkendala macet dan waktu tempuh menjadi ontime. (6) Tidak perlu repot untuk keluar rumah. Cukup telepon atau pesan lewat aplikasi (ojek online). (7) dapat memenuhi kebutuhan angkutan konsumen disaat angkutan umum tidak bias melayaninya, seperti ke tempattempat yang bukan merupakan trayek angkutan umum.

Memperhatikan latar belakang kemunculan dan nilai-nilai manfaat kehadiran motorcycle taxi diatas, membawa penulis kepada satu kesimpulan bahwa motorcycle taxi adalah "solusi angkutan yang mashlahah" dalam memenuhi kebutuhan konsumen terhadap angkutan. Maslahab" adalah kegunaan (manfa'ab), demikian menurut Ibn Manzur dalam Lisan al-'Arabi-nya. ${ }^{23}$

Angkutan ojek dilihat dari mashlahah Al-Syatibi, juga memenuhi unsur mashalah, sebab angkutan ojek hadir dalam rangka untuk menyokong kebutuhan manusia, baik kebutuhan pindahan yang tepat waktu, lancar dan mudah maupun kebutuhan untuk mengangkut barang bawaan. Hal ini sesuai dengan mashalah yang didefinisikan oleh Al-Syatibi sebagai segala sesuatu yang dibutuhkan untuk menyokong kehidupan manusia dan kelengkapan hidupnya, baik yang bersifat jasmani ataupun rohani sehingga merasa nyaman dalam hidup. ${ }^{24}$

Sementara jika dilihat dari mashalah-nya Al-Ghazaliy ${ }^{25}$ dan Al-Bhutiy ${ }^{26}$, yang mana keduanya sama-sama mendefinisikan mashlahah sebagai sesuatu

23 Ibn Manzur, Lisan al-'Arabi (Cairo : Dar al-hadith, 2003), Vol. V, hal. 347; Muhammad Sayyid Ramadan al- Buti, Dawabit al-Maslahah fi Shari'at al-Islamiyyah (Beirut : Muassasah al-Risalah, 2001), h. 27.

24 Abu Ishaq al-Syatibiy, al-Muwafaqat fi usul al-shari'ah (Beirut: Dar Al-Kutub Al-Arabi, 2002), h. 213.

25 Abu Hamid al-Ghazali, Al-Mustasfa fi Ilmi al-Ushul, Juz 2 (Madinah Munawwarah: Islamic University, 1992), h. 481.

26 Muhammad Said Ramadan al-Buti, Dawabit Al-Maslahah Fi Al-Shariah Al-Islamiyyah (Beirut: Muassasah Al-Risalah, t.th), h. 23. 
yang memiliki daya guna (manfaah), maka dari sini sulit untuk disangkal bahwa angkutan ojek dengan segala manfaat solutifnya bagi ketidakberdayaan angkutan umum, keluar dari koridor mashlahah. Begitupun dalam perspektif mashalah al-Suyuthi ${ }^{27}$ yang mengatakan bahwa maslahab adalah bentuk perwujudan kebaikan itu sendiri. Angkutan ojek itu kebaikan itu sendiri dan kebaikan bagi yang lain, kebaikan bagi ojek sendiri dapat menjadi saran mendatang income dan kebaikan bagi yang lain (konsumen) dapat memenuhi kebutuhan transportasinya dengan cepat.

Pada aspek tingkatan mashalahah, angkutan ojek bisa masuk ke beberapa tingkat tergantung posisi dari angkutan ojek itu sendiri. Jika angkutan ojek itu sebagai profesi tempat bergantung mencari nafkah bagi keluarga tukang ojek, maka angkutan ojek itu tersebut berada pada posisi daruriyah.

Selain hal di atas, angkutan ojek menduduki posisi daruriyat, menurut penulis apabila rasio Kendaraan Bermotor umum untuk Angkutan orang belum memadai dalam hal kapasitas Angkutan orang dengan Kendaraan Bermotor umum berupa, Mobil Bus, dan Mobil Penumpang yang ada belum dapat memenuhi kebutuhan Angkutan orang. Seperti yang terjadi dipulau Kangean, dimana rasio angkutan orang dengan kendaraan umum sangat minim kalau tidak bisa dikatakan tidak ada sama sekali. Di pulau Kangean angkutan orang dengan ojek merupakan satu-satunya angkutan yang menjadi denyut nadi pergerakan ekonomi masyarakat, satu-satunya angkutan yang memenuhi kebutuhan dasar masyarakat akan transportasi yang bisa mengantar ke tempat tujuan yang dikehendakinya. Dengan demikian dapat dipahami bahwa posisi motorcycle taxi (ojek) berada pada level daruriyah tergantung spesifikasi daerah dan keberadaan angkutan umumnya.

Angkutan ojek berada pada posisi hajizat (pendukung) apabila ia hadir ditegah rasio Kendaraan Bermotor umum untuk Angkutan orang memadai dalam hal kapasitas Angkutan orang dengan Kendaraan Bermotor umum berupa, Mobil Bus, dan Mobil Penumpang, namun dalam keadaan tertentu karena padatnya lalu lintas (macet), ia bisa menjadi opsi yang solutif bagi pengguna angkutan umum sebagai sarana transportasi yang bisa menghantarkan ke tempat tujuan tepat waktu. Ojek dalam konteks ini merupakan sebuah moda transportasi yang menjadi salah satu primadona angkutan alternatif, karena dianggap paling efektif sebab mampu memecah kemacetan dengan segala keluwesannya ke semua penjuru kota.

27 Jalal al-Din al-Suyuthi, Al-Ashbah wa Al-Nadzair (Beirut, Dar al-Fikr, tth), h. 16 
Ojek berada pada posisi tatimmat/takammulat, tabsiniyah (pelengkap) apabila ia hadir ditegah rasio Kendaraan Bermotor umum untuk Angkutan orang memadai dalam hal kapasitas Angkutan orang dengan Kendaraan Bermotor umum berupa, Mobil Bus, dan Mobil Penumpang, kehadiran ia memberi

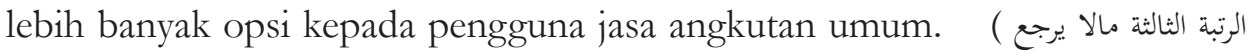
الى ضرورة ولاإلى حاجة, ولكن يقع موقع التحسين والتزيين والتيسير للمزايا والمزائد ورعاية أحسن المناهج فن العادات Bagi al-Ghazali, mashlahah Tabsiniyyat adalah peringkat memperbaiki, memperindahkan serta mempermudahkan suatu keadaan supaya mendatangkan nilai tambah, baik dalam urusan harian ataupun muamalat. ${ }^{28}$

Kemudian dari segi cakupannya, angkutan ojek masuk kepada mashlalah dunyawi. Hal ini bisa dilihat dari manfaat angkutan ojek dalam menopang kebutuhan-kebutahan pokok yang lazim harus terpenuhi oleh manusia di dalam kehidupan ini. Misalnya, makan, minum, pakaian, tempat tinggal dan lain sebagainya. Selain itu, angkutan ojek juga berkaitan dengan kebanyakan orang, baik di masyarakat kota maupun masyarakat desa, ojek merupakan sebuah moda transportasi yang menjadi salah satu primadona angkutan alternatif, karena dianggap paling efektif dan mampu memecah kemacetan dengan segala keluwesannya menuju destinasi penumpang.

Nilai-nilai kemaslahatan yang terkandung dalam angkutan motorcyle taxi lebih terasa saat diintegrasikan dengan aplikasi transportasi online, seperti grab bike dan go ride, konsumen cukup menggunakan smartphonenya untuk mengakses transportasi yang diinginkan dengan tanpa meninggalkan tempat duduknya, dan transportasi keinginannya akan menemuinya didepan rumah.

\section{Urgensi Perlindungan Hukum Terhadap Konsumen Angkutan Orang dengan Menggunakan Sepeda Motor (Ojek)}

Pelayanan transportasi merupakan upaya pemecahan masalah kesenjangan jarak dalam melakukan suatu aktivitas. Transportasi berfungsi sebagai suatu rantai (chain of transportation) yang menghubungkan produsen dengan konsumen dengan melibatkan berbagai unsur kegiatan usaha transport atau moda transport. Dalam hal ini kegiatan pemindahan barang ataupun orang dapat dilakukan dengan berbagai moda transportasi baik karena kondisi moda sendiri maupun kondisi wilayahnya. Terkait dengan hal tersebut sebagian besar pergantian moda terjadi pada kota-kota tertentu yang membutuhkan moda lebih dari satu dalam melakukan pergerakannya. Terlebih jika pelayanan moda transportasi tidak mampu menjangkau daerah tujuan, maka diperlukan moda lain sebagai penghubung antara

28 Abu Hamid al-Ghazali, Al-Mustasfa fi Ilmi al-Ushul, Juz 2 (Madinah Munawwarah: Islamic University, 1992), h. 290 
kota satu dengan yang lainnya atau antara kota.

Secara umum, masyarakat yang melakukan pergerakan dengan tujuan yang berbeda-beda membutuhkan sarana penunjang pergerakan berupa angkutan pribadi (mobil, motor) maupun angkutan umum (paratransit dan masstransit). Angkutan umum paratransit merupakan angkutan yang tidak memiliki rute dan jadwal yang tetap dalam beroperasi disepanjang rutenya, sedangkan angkutan umum masstransit merupakan angkutan yang memiliki rute dan jadwal yang tetap serta tempat pemberhentian yang jelas.

Pada umumnya sebagian besar masyarakat sangat tergantung dengan angkutan umum bagi pemenuhan kebutuhan mobilitasnya, karena sebagian besar masyarakat tingkat ekonominya masih tergolong lemah atau sebagian besar tidak memiliki kendaraan pribadi. Banyaknya kelompok yang masih tergantung dengan angkutan umum ini nampaknya tidak diimbangi dengan penyediaan angkutan umum yang memadai, terutama ditinjau dari kapasitas angkut, rasionya dan trayeknya yang terbatas. Akibatnya hampir semua angkutan umum yang tersedia terisi penuh sesak oleh penumpang. Hal ini menyebabkan para penumpang berusaha memilih alternatif angkutan lainnya yang dirasa lebih nyaman, efektif dan efisien dan bisa mengantarkan ketempat tujuan dengan aman.

Peran angkutan umum sangat penting bagi kehidupan kota, hal ini tidak dapat dipungkiri bahwa dalam kenyataannya angkutan umum merupakan sarana yang dibutuhkan oleh sebagian besar masyarakat baik di perkotaan maupun di pedesaan, karena bagaimanapun juga pasti ada sekelompok masyarakat yang tergantung pada angkutan umum untuk memenuhi kebutuhan mobilitasnya dengan alasan tidak dapat menggunakan kendaraan pribadi, baik karena alasan fisik (terlalu kecil, sakit atau tua), alasan legal (tidak memiliki SIM) atau alasan finansial (tidak memiliki kendaraan pribadi)

Pihak yang berkewajiban dan yang bertanggung jawab terhadap terpenuhinya kebutuhan transportasi ini adalah pemerintah. Hal ini dijelaskan secara tegas dalam Pasal 138 Undang-Undang No. 22 Tahun 2009, ayat (2) disebutkan bahwa Pemerintah bertanggung jawab atas penyelenggaraan angkutan umum. Kemudian dalam Pasal 238 ayat (1) disebutkan bahwa Pemerintah menyediakan dan/atau memperbaiki pengaturan, sarana, dan Prasarana Lalu Lintas yang menjadi penyebab kecelakaan. Begitu juga dalam Pasal 139 ayat (1) menyebutkan bahwa pemerintah wajib menjamin tersedianya angkutan umum untuk jasa angkutan orang dan/atau barang antarkota antarprovinsi serta lintas batas negara.

Disisi lain intensitas kegiatan pada daerah perkotaan semakin meningkat seiring perkembangan ekonomi. Intensitas yang tinggi ini membutuhkan sarana 
transportasi yang memadai. Sarana yang memadai disini yaitu angkutan yang dapat dengan cepat mencapai tujuan. Dewasa ini masyarakat cenderung memilih angkutan yang lebih fleksibel dan cepat untuk mencapai tujuan walaupun ongkosnya lebih besar. Angkutan alternatif yang dipilih masyarakat salah satunya adalah angkutan ojek/ motorcycle taxi, yang memiliki mobilitas lebih tinggi dibandingkan angkutan umum.

Sebagai sarana angkutan, ojek dinilai banyak memberi keuntungan bagi golongan masyarakat tertentu yang bersifat rutin maupun berkala dibutuhkan dalam menunjang pergerakan. Keuntungan lain dari sarana ini lebih disebabkan karena lingkup pelayanan yang tidak dibatasi oleh rute-rute tetentu seperti angkutan umum lainnya serta tidak memiliki jadwal yang tetap. Angkutan ojek ini mampu memberikan pelayanan yang bersifat dari pintu ke pintu (sampai ke rumah).

Keberadaan angkutan ojek ini amat berguna dalam memberikan pelayanan bagi masyarakat tertentu terutama pada daerah yang belum terjangkau oleh angkutan umum. Keberadaan angkutan ojek ini merupakan bagian dari sistem transportasi perkotaan. Pangsa pasar dari jenis angkutan ini adalah sebagai penerus (feeder) dari angkutan lainnya.

Undang-Undang No. 22 Tahun 2009 tentang Lalu Lintas dan Angkutan Jalan dan Peraturan Pemerintah No. 74 Tahun 2014 merupakan dasar hukum bagi aktivitas pengangkutan orang di darat. Pasal 137 Undang-Undang No. 22 Tahun 2009 ayat (1) dinyatakan bahwa Angkutan orang dan/atau barang dapat menggunakan Kendaraan Bermotor dan Kendaraan Tidak Bermotor. Kemudian Pasal 138 ayat (3) menegaskan bahwa Angkutan umum orang dan/atau barang hanya dilakukan dengan Kendaraan Bermotor Umum. Sepeda motor bukan kendaraan bermotor umum

Kata "hanya" menurut Kamus Besar Bahasa Indonesia sinonim dengan: (1) Cuma, (2) kecuali (3) tetapi (4) tidak lebih dari (5) tidak lain dari, (6) saja. ${ }^{29}$ Cuma bermakna "tidak ada yang lain (sendirian dalam jenisnya)" 30 kemudian "saja" bermakna "melulu (tiada lain hanya; semata-mata)". ${ }^{31}$ Dengan demikian, bedasarkan arti dari kata "hanya" dalam Pasal 138 ayat (3) Undang-Undang No. 22 Tahun 2009 di atas, tidak ada peluang hukum bagi legalitas angkutan ojek di Indonesia di dalam undang-undang tersebut.

Terdapat catatan kritis terhadap Pasal 138 UU No. 22 Tahun 2009 yang menjadi pangkal terlarangnya sepeda motor sebagai salah satu moda angkutan umum orang di Indonesia. Penelurusan terhadapa pasal-pasal yang ada dalam UU 29 http://kbbi.web.id/hanya. diakses tanggal 26 Mei 2016 jam 16.36 WIB. 30 http://kbbi.web.id/hanya. diakses tanggal 26 Mei 2016 jam 16.36 WIB. 31 http://kbbi.web.id/hanya. diakses tanggal 26 Mei 2016 jam 16.36 WIB. 
No. 22 Tahun 2009, tidak ada ketentuan pidana bagi penggunaan sepeda motor sebagai angkutan umum orang. Hal ini menarik jika dilihat dari pendapat Austin yang menyatakan bahwa hukum mengandung empat (4) unsur, yaitu: perintah, sanksi, kewajiban dan kedaulatan. Unsur-unsur ini harus ada dalam norma hukum. Jika norma hukum sudah mengandung ke-empat (4) unsur di atas, maka menurut Austin hal tersebut positive law, dan jika norma hukum tidak memenuhi empat (4) unsur di atas, maka hal itu disebut positive morality. ${ }^{32}$

Tidak adanya ketentuan pidana untuk mengantisipasi pelanggaran terhadap Pasal 138 ayat (3) di atas, maka hal ini bisa menyebabkan ketidakpastian hukum. Ketidakpastian ini bisa terjadi manakala Pasal 138 ayat (3) di atas diterjemahkan ketika terjadi pelanggaran, maka multitafsir ketentuan pidananya akan menyeruak kepermukaan sehingga mengakibatkan ketidakpastian hukum. Menurut ahli, Kepastian hukum dapat kita lihat dari dua sudut, yaitu kepastian dalam hukum itu sendiri dan kepastian karena hukum. "Kepastian dalam hukum" dimaksudkan bahwa setiap norma hukum itu harus dapat dirumuskan dengan kalimat-kalimat di dalamnya tidak mengandung penafsiran yang berbeda-beda. Akibatnya akan membawa perilaku patuh atau tidak patuh terhadap hukum. Dalam praktek banyak timbul peristiwa-peristiwa hukum, di mana ketika dihadapkan dengan substansi norma hukum yang mengaturnya, kadangkala tidak jelas atau kurang sempurna sehingga timbul penafsiran yang berbeda-beda yang akibatnya akan membawa kepada ketidakpastian hukum. ${ }^{33}$

Dengan tidak adanya kepastian hukum, maka pemerintah gagal memberikan perlindungan hukum kepada kepada masyarakat. Perlindungan hukum sendiri menurut Satjipto Rahardjo bertujuan untuk mengintegrasikan berbagai kepentingan tertentu dapat dilakukan dengan cara membatasi berbagai kepentingan dilain pihak. Kepentingan hukum adalah mengurusi hak dan kepentingan manusia, sehingga kepentingan manusia yang perlu diatur dan dilindungi. ${ }^{34}$

Berdasarkan teori perlindungan hukum versi Satjipto Rahardjo di atas, Undang-Undang No. 22 Tahun 2009 seharusnya mengintegrasikan kepentingan pengguna jasa dan pelaku usaha jasa transportasi, undang-undang ini hadir dalam rangka mengurusi dan melindungi hak masyarakat atas kebutuhannya terhadap jasa transportasi, hanya saja norma yang mengaturnya terkait dengan motorcyle

32 Soerjono Soekanto, Pokok-Pokok Sosiologi Hukum (Jakarta: Rajawali Pers, 2014), h. 35.

33 Syafruddin Kalo, Penegakan Hukum Yang Menjamin Kepastian Hukum Dan Rasa Keadilan Masyarakat Suatu Sumbangan Pemikiran. Makalah disampaikan pada "Pengukuhan Pengurus Tapak Indonesia Koordinator Daerah Sumatera Utara”, pada hari Jum'at, 27 April 2007, bertempat di Gayo Room Garuda Plaza Hotel, Jl. Sisingamangaraja No. 18 Medan, h. 4. 34 Satjipto Rahardjo, Ilmu Hukum (Bandung: PT. Citra Adtya Bakti, 2000), h. 53. 
taxi tidak lengkap, yang pada akhirnya justru hak pengguna jasa transportasi tersebut tidak terlindungi. Aktivitas Motorcyle Taxi ada karena faktor kebutuhan masyarakat, ${ }^{35}$ kebutuhan ini seharusnya direspon oleh hukum untuk dilindungi, karena hukum bukan untuk dirinya tapi untuk manusia.

Hukum dapat difungsikan untuk mewujudkan perlindungan, sifatnya tidak hanya adaftif dan fleksibel, melainkan prediktif dan antipatif. ${ }^{36}$ Angkutan orang dengan motorcyle taxi (ojek) merupakan kenyataan yang telah diterima oleh masyarakat umum apalagi saat ini diintegrasikan dengan aplikasi seperti Go Ride dan Grab Bike, aturan hukum seharusnya adaftif dengan kenyataan yang terus berkembang ini, apalagi kenyataan ini telah memberikan kemaslahatan bagi pengguna jasanya dan pelaku usahanya sebagaimana telah diuraikan pada bagian sebelumnya.

Angkutan dengan motorcycly taxi sebenarnya bisa diprediksi dan bisa diantisipasi kehadirannya, sebab angkutan umum belum merata seluruh pelosok negeri dan belum memainkan peran secara maksimal dan sempurna, motorcycly taxi dilihat dari sejarahnya lebih dulu ada daripada Undang-Undang No.22 Tahun 2009 (UU LLAJ) namun lepas dari pengamatan karena tidak memenuhi aspek keselamatan ${ }^{37}$ atau berbenturan dengan landasan filosofis (keselamatan) dari UU LLAJ ${ }^{38}$ sehingga sepeda motor (motorcyle) tidak diprediksi sebagai salah satu angkutan umum, padahal masyarakat telah menggunakannya untuk kepentingannya jauh sebelum undang-undang ini ada, norma hukum seharusnya alur penyusunananya bottom up bukan top down. Aspirasi hukum seharusnya dari kenyataan di masyarakat, sehingga hukum responsif terhadap kepentingan masyarakat dan bisa selaras dengan living law (hukum yang hidup di masyarakat).

Setelah sepeda motor dijadikan angkutan umum secara sepihak oleh pelaku usaha dan pengguna jasa, karena dibutuhkan oleh kedua dan merupakan

35 lihat Geistiar Yoga Pratama dan Suradi Aminah, Perlindungan Hukum Terhadap Data Pribadi Pengguna Jasa Transportasi Online Dari Tindakan Penyalahgunaan Pihak Penyedia Jasa Berdasarkan Undnag-Undang No. 8 Tahun 1999 tentang Perlindungan Konsumen, Diponegoro Law Journal, Vol. 5 No. 3 Tahun 2016, h. 3.

36 Lili Rasjidi dan I.B Wysa Putra, Hukum Sebagai Suatu Sistem (Bandung: Remaja Rosdakarya, 1993), h. 118.

37 Undang-undang No. 22 Tahun 2009 memang tida mencantumkan sepeda motor sebagai sarana transportasi publik dengan pertimbangan utamanya tidak layak pada aspek keselamatan, lihat Geistiar Yoga Pratama dan Suradi Aminah, Perlindungan Hukum Terhadap Data Pribadi Pengguna Jasa Transportasi Online Dari Tindakan Penyalahgunaan Pihak Penyedia Jasa Berdasarkan Undnag-Undang No. 8 Tahun 1999 tentang Perlindungan Konsumen, Diponegoro Law Journal, Vol. 5, No. 3 Tabun 2016, hal. 3.

38 Putusan Mahkamah Konstitusi No. 41/PUU-XVI/2018. 
solusi alternatif atas masalah akses transportasi publik yang mendapat reposn positif dari masyarakat luas, ${ }^{39}$ baik yang offline ( ojek pangkalan) maupun yang diintegrasikan dengan aplikasi (transportasi online), ${ }^{40}$ barulah negara merespon dengan mengeluarkan Peraturan Pemerintah No. 12 Tahun 2019 tentang Perlindungan Keselamatan Pengguna Sepeda Motor yang Digunakan untuk kepentingan Masyarakat. Berdasarkan peraturan menteri ini ternyata landasan filosofis sebuah undang-undang bisa berubah, landasan filosofi UULAJ adalah pemenuhan keselamatan dan pada saat itu sepeda motor belum memenuhinya, dan pada saat ini dengan keluarnya peraturan menteri sebagaimana telah disebutkan menyatakan sepeda motor memenuhi aspek keselematan sebagaimana termaktub dalam Pasal 4 peraturan menteri tersebut. ${ }^{41}$ Peraturan menteri ini responsif, prediktif, adaftif dan antipatif, hanya saja tidak harmonis secara vertikal dengan undang-undang yang lebih tinggi, yaitu Undang-Undang No. 22 Tahun 2009, sehingga berlaku asas lex posterior legi inferiori (hukum yang yang lebih tinggi mengeliminasi hukum yang lebih rendah).

Motorcyclycle taxi baik yang online maupun yang pangkalan memang tidak dapat dikategorikan sebagai angkutan umum karena tidak memenuhi kriteria angkutan umum, tidak tegasnya pengaturannya menyebabkan ketidakpastian hokum, pilihan untuk mmembiarkannya dengan tidak mengaturnya bukan jawaban yang tepat. Hukum harus hadir untuk memberikan kepastian hukum, ketertiban dan kemanfaatan bagi masyarakat. ${ }^{42}$ Perlindungan hukum merupakan

39 lihat Geistiar Yoga Pratama dan Suradi Aminah, Perlindungan Hukum Terhadap Data Pribadi Pengguna Jasa Transportasi Online Dari Tindakan Penyalahgunaan Pihak Penyedia Jasa Berdasarkan Undang-Undang No. 8 Tahun 1999 tentang Perlindungan Konsumen, Diponegoro Law Journal, Vol. 5 No. 3 Tahun 2016, h. 3.

40 Transportasi jalan online adalah transportasi dengan menggunakan media internet, Olga A. Pangkerego dan Friend H. Anis, Aspek Hukum Pelrindungan Konsumen Terhadap Jasa Transportasi Online Menurut Undang-Undang No. 8 Tahun 1999 tentang Pelrindungan Konsumen, Jurnal Lex Privatum, Vol. VI No. 3 Tahun 2018, h. 91.

41 Aspek keselmatan Penggunaan Sepeda Motor yang digunakan untuk kepentingan masyarakat adalah: a,pengemudi dalam keadaan sehat; b. Pengemudi menggunakan kendaraan bermotor dengan Surat Tanda Kendaraan Bermotor yang masih berlaku; c. Pengemudi memiliki Surat Izin Mengemudi C; d. Pengemudi memiliki Surat Izin Mengemudi D untuk mengemudikan kendaraan khusus bagi penyandang disabilitas; e. Pengemudi mematuhi tata cara berlalu lintas dijalan; f. Pengemudi tidak membawa Penumpang melebihi dari 1 (satu) orang; g. pengemudi menguasai wilayah operasi; $h$. Pengemudi menggunakan kendaraan yang memenuhi persyaratan teknis sesuai dengan ketentuan peraturan perundang-undangan; i. Pengemudi melakukan pengecekan terhadap kendaraan yang akan dioperasikan; j. Pengemudi melakukan perawatan kendaraan sesuai dengan jadwal yang telah ditetapkan dalam buku perawatan yang dikeluarkan oleh Agen Pemegang Merek; k. Pengemudi mengendarai Sepeda Motor dengan wajar dan penuh konsentrasi;

42 Agus Suwandono, Pendekatan Holistik Transportasi berbasis Aplikasi Dalam Kerangka Hukum Perlindungan Konsumen, Jurnal Mimbar Hukum, Vol. 31 No. 1 Tahun 2019, h. 56. 
ilustrasi dari bekerjanya hukum untuk mewujudkan tujuan hukum, yaitu keadilan, kemanfaatan dan kepastian hukum

Berdasarkan diskusi di atas, secara otomatis dibidang perlindungan konsumen, negara juga belum hadir dalam memberikan pelrindungan. Padahal menurut Pasal 29 (1) Undang-Undang No. 8 Tahun 1999 disebutkan bahwa Pemerintah bertanggungjawab atas pembinaan penyelenggaraan perlindungan konsumen yang menjamin diperolehnya hak konsumen dan pelaku usaha serta dilaksanakannya kewajiban konsumen dan pelaku usaha. Sementara perlindungan konsumen dipahami sebagai upaya yang menjamin adanya kepastian hukum untuk memberi perlindungan kepada konsumen dan salah satu asas dari perlindungan konsumen adalah asas kepastian hukum, yang dimaksudkan kepastian hukum dalam perlindungan konsumen adalah agar baik pelaku usaha maupun konsumen menaati hukum dan memperoleh keadilan dalam penyelenggaraan perlindungan konsumen, serta negara menjamin kepastian hukum.

Dalam angkutan ojek pada hakikatnya diawali dengan perjanjian antara tukang ojek dengan konsumen, perjanjiannya terjadi baik secara tulisan, lisan maupun isyarat. Ketika konsumen menyatakan kehendaknya baik dengan lisan, tulisan maupun dengan isyarat, dan tukang ojek menerima pernyataan kehendak konsumen tersebut, maka telah terjadi perjanjian yang mengikat dan menimbulkan hak dan kewajiban diantara keduanya. Kewajiban konsumen adalah membayar upah tukang ojek yang menjadi haknya tukang ojek, dan kewajiban tukang ojek adalah mengantar konsumen ketempat tujuan dengan selamat yang menjadi haknya dari konsumen.

Akan tetapi di dalam Pasal 130 Kitab Udang-Undang Hukum Perdata (KUHPer), terdapat beberapa syarat sahnya perjanjian, yaitu: (1) Cakap Hukum, ${ }^{43}$

43 Pasal 1329 KUHPerdata menyatakan bahwa setiap orang adalah cakap untuk membuat perjanjian, kecuali apabila menurut undang-undang dinyatakan tidak cakap. Kemudian Pasal 1330 menyatakan bahwa ada beberapa orang yang tidak cakap untuk membuat perjanjian, yakni: (1) Orang yang belum dewasa (dibawah 21 tahun, kecuali yang ditentukan lain) (2) Mereka yang ditaruh di bawah pengampuan (curatele or conservatorship); dan (3) Perempuan yang sudah menikah. Berdasarkan pasal 330 KUHPerdata, seseorang dianggap dewasa jika 
(2) bersepakat ${ }^{44}(3)$ tentang suatu hal tertentu, ${ }^{45}(4)$ causa halal. ${ }^{46}$ Syarat pertama dan kedua disebut syarat subyektif. Karena kedua syarat tersebut harus dipenuhi oleh subyek hukum. Sedangkan syarat ketiga dan keempat disebut sebagai syarat obyektif karena kedua syarat ini harus dipenuhi oleh obyek perjanjian.

Menurut Subekti, suatu perjanjian yang tidak memenuhi syarat subyektif dapat dimintakan pembatalan (cancelling) oleh salah satu pihak..$^{47}$ Suatu perjanjian yang tidak memenuhi syarat obyektif berakibat perjanjian yang dibuat batal demi hukum, dimana secara yuridis dipandang bahwa dari semula tidak ada perjanjian dan tidak ada pula suatu perikatan antara orang-orang yang bermaksud membuat perjanjian itu. ${ }^{48}$

dia telah berusia 21 tahun atau kurang dari 21 tahun tetapi telah menikah..

44 Pasal 1321 - 1328 Supaya perjanjian menjadi sah maka para pihak harus sepakat terhadap segala hal yang terdapat di dalam perjanjian dan memberikan persetujuannya atau kesepakatannya jika ia memang menghendaki apa yang disepakati. Dalam preambule perjanjian (sebelum masuk ke pasal-pasal), biasa tuliskan sebagai berikut "Atas apa yang disebutkan diatas, Para Pihak setuju dan sepakat hal-hal sebagai berikut:" Pencantuman kata-kata setuju dan sepakat sangat penting dalam suatu perjanjian. Tanpa ada kata-kata ini (atau kata-kata lain yang bermaksud memberikan ikatan atau setuju saja atau sepakat saja), maka perjanjian tidak memiliki ikatan bagi para pembuatanya. Setuju dan sepakat dilakukan dengan penuh kesadaran di antara para pembuatnya, yang bisa diberikan secara lisan dan tertulis. Suatu perjanjian dianggap cacat atau dianggap tidak ada apabila: (1) mengandung paksaan (dwang), termasuk tindakan atau ancaman atau intimidasi mental. (2) mengandung penipuan (bedrog), adalah tindakan jahat yang dilakukan salah satu pihak, misal tidak menginformasikan adanya cacat tersembunyi. (3) mengandung kekhilafan/kesesatan/kekeliruan(dwaling), bahwa salah satu pihak memiliki persepsi yang salah terhadap subyek dan obyek perjanjian. Terhadap subyek disebut error in persona atau kekeliruan pada orang, misal melakukan perjanjian dengan seorang artis, tetapi ternyata perjanjian dibuat bukan dengan artis, tetapi hanya memiliki nama dengan artis. Terhadap obyek disebut error in substantia atau kekeliruan pada benda, misal membeli batu akik, ketika sudah dibeli, ternyata batu akik tersebut palsu

45 Pasal 1333 KUHPerdata menentukan bahwa suatu perjanjian harus mempunyai pokok suatu benda (zaak)yang paling sedikit dapat ditentukan jenisnya. Suatu perjanjian harus memiliki objek tertentu dan suatu perjanjian haruslah mengenai suatu hal tertentu (certainty of terms), berarti bahwa apa yang diperjanjikan, yakni hak dan kewajiban kedua belah pihak. Barang yang dimaksudkan dalam perjanjian paling sedikit dapat ditentukan jenisnya (determinable).

46 Menurut Pasal 1335 jo 1337 KUHPerdata menyatakan bahwa suatu kausa dinyatakan terlarang jika bertentangan dengan undang-undang, kesusilaan, dan ketertiban umum. Suatu kausa dinyatakan bertentangan dengan undang-undang, jika kausa di dalam perjanjian yang bersangkutan isinya bertentangan dengan undang-undang yang berlaku. Untuk menentukan apakah suatu kausa perjanjian bertentangan dengan kesusilaan (geode zeden) bukanlah hal yang mudah, karena istilah kesusilaan tersebut sangat abstrak, yang isinya bisa berbeda-beda antara daerah yang satu dan daerah yang lainnya atau antara kelompok masyarakat yang satu dan lainnya. Selain itu penilaian orang terhadap kesusilaan dapat pula berubah-ubah sesuai dengan perkembangan jaman.

47 Subekti, Hukum Perjanjian (Jakarta: Intermasa, 2002), h. 22.

48 Subekti, Hukum Perjanjian, h. 22. 
Dilihat dari aspek hukum perjanjian ini, maka perjanjian angkutan ojek bermasalah pada aspek syarat obyektifnya, yaitu: sebab halal. Sebab yang halal ialah tujuan antara dua belah pihak yang mempunyai maksud untuk mencapainya. Menurut Pasal 1337 KUHPerdata, sebab yang tidak halal ialah jika ia dilarang oleh undang-undang, bertentangan dengan tata susila atau ketertiban. Menurut Pasal 1335 KUHPerdata, perjanjian tanpa sebab yang palsu atau dilarang tidak mempunyai kekuatan atau batal demi hukum.

Sebab tidak halal dalam perjanjian angkutan ojek adalah tujuan antara dua belah pihak yang mempunyai maksud untuk mencapainya yaitu"angkutan dengan sepeda motor", sepeda motor menurut Undang-Undang No. 22 Tahun 2009 dan Peraturan Pemerintah No. 74 Tahun 2009 bukan merupakan kendaraan bermotor umum sehingga legal digunakan untuk angkutan umum di Indonesia sebagaimana dijelaskan dalam Pasal 138 ayat (3) Undang-Undang No. 22 Tahun 2009 menegaskan bahwa Angkutan umum orang dan/atau barang hanya dilakukan dengan Kendaraan Bermotor Umum. Kendaraan Bermotor Umum adalah setiap Kendaraan yang digunakan untuk angkutan barang dan/atau orang dengan dipungut bayaran. Yang termasuk kendaraan umum adalah mobil bus dan mobil penumpang (lihat skema).

Berdasarkan hal di atas, maka yang dapat diketahui bahwa konsumen menjadi tidak terlindungi karena perjanjian antara tukang ojek dan konsumen batal demi hukum karena tidak terpenuhi syarat obyektifnya "causa halal". Kausa halal dalam perjanjian pengangkutan adalah yang menjadi obyek dari perjanjian antara tukang ojek dan konsumen yaitu angkutan orang dengan ojek (sepeda motor), dasar tidak terpenuhinya kausa halal ini adalah karena menurut Pasal 138 (ayat) Angkutan umum orang dan/atau barang hanya dilakukan dengan Kendaraan Bermotor Umum. Kendaraan Bermotor Umum adalah setiap Kendaraan yang digunakan untuk angkutan barang dan/atau orang dengan dipungut bayaran. Yang termasuk kendaraan umum adalah mobil bus dan mobil penumpang bukan sepeda motor.

Dengan ini, maka semua konsumen angkutan ojek tidak mendapat perlindungan hukum di Negara yang berdasarkan hukum ini, padahal walaupun tidak ada data yang pasti secara matematis, konsumen angkutan ojek membentang dari Sabang-Merauke, sebab angkutan ojek sebagaimana telah penulis paparkan adalah solusi yang sangat solutif dan mashlahah bagi kebutuhan masyarakat terhadap transportasi.

Angkutan ojek telah ada sejak tahun 80-an, dan Undang-Undang No. 22 Tahun 2009 baru Pada tanggal 22 Juni 2009 diundangkan. Tidak diakomodirnya 
sepeda motor sebagai salah satu moda angkutan umum seperti di Negara-negara lain, menurut penulis terdapat kelalaian dalam penyusunan Naskah Akademik Undang-Undang No. 22 Tahun 2009 di atas. Naskah akademik suatu undangundang disusun melalui sebuah penelitian sebagaimana dijelaskan dalam Pasal 1 angka 11 UU Nomor 12 Tahun 2011 tentang Pembentukan Peraturan Perundang-undangan, naskah akademik adalah naskah hasil penelitian atau pengkajian hukum dan hasil penelitian lainnya terhadap suatu masalah tertentu yang dapat dipertanggungjawabkan secara ilmiah mengenai pengaturan masalah tersebut dalam suatu Rancangan Undang-undang. Bagaimana mungkin aktivitas angkutan ojek yang membentang dari Sabang-Merauke lepas dari pengamatan penyusun naskah akademik dan pembahas naskah akademik. Alasannya mungkin karena angkutan ojek merupakan kepentingan kaum "proletar" sehingga tidak perlu diakomodir dalam aturan. Jika ini benar maka semakin mempertegas dan membuktikan pernyataan Karl Marx (1818-1883) bahwa hukum adalah alat yang menyebabkan timbulnya konflik dan perpecahan. Hukum tidak berfungsi untuk melindungi (kaum proletar). Hukum hanya melindungi kelompok-kelompok yang dominan (pengusaha, pemodal, kapital). ${ }^{49}$ Hukum dan kekuasaan merupakan sarana dari kaum kapitalis yang berkuasa di bidang ekonomi, untuk melanggengkan kekuasaan..$^{50}$

Selain mempertegas dan membuktikan pernyataan Karl Marx di atas, kejadian ini juga patut diduga membenarkan pernyataan Satjipto Rahardjo bahwa undangundang itu cacat sejak lahir, karena di dalamnnya terdapat kepentingan-kepentingan pembuatnya, sehingga tidak lagi murni dari hati nurani yang memperhatikan nasib masyarakat secara keseluruhan ${ }^{51}$.

Keterbatasan ketersediaan transportasi dapat menyebabkan tersendatnya mobilitas masyarakat untuk memenuhi hak sosial masyarakat dalam bentuk mobilisasi masyarakat yang dinamis. ${ }^{52}$ Oleh karena itulah, keberadaan dan ketersediaan pelayanan jasa angkutan umum yang memadai ini menjadi persoalan penting yang perlu diberi perhatian. Kebutuhan dan tuntutan masyarakat terhadap angkutan umum baik di kota besar ataupun kota kecil inilah yang akhirnya menjadi satu dari beberapa faktor munculnya kendaraan-kendaraan angkutan umum yang informal dan bersifat alternatif seperti angkutan ojek ini.

49 Yesmil Anwar \& Adang, Pengantar Sosiologi Hukum, (Jakarta: PT. Grasindo, 2008), h. 133.

50 Yesmil Anwar \& Adang, Pengantar Sosiologi Hukum, h. 133.

51 Baca: Hukum Progresif, Satjipto Rahardjo. Undang-undang itu dibuat oleh DPR, DPR itu berasal dari partai politik, setiap partai politik memiliki kepentingan yang berbeda-beda yang cenderung mengamankan kepentingan politiknya, sehingga produk hukum yang diciptakanya pun tidak jauh dari interfevsi kepentingan politiknya, inilah yang dinamakan hukum itu cacat sejak lahir.

52 Zaini Noer \& Usman Melayu, Kebijakan Transportasi, Simposium III FSTPT, Jakarta, 2000, h. 5. 
Dalam konteks ini, pemerintah bisa mengajukan revisi Undang-Undang No. 22 Tahun 2009 kepada Dewan Perwakilan Rakyat dan mengakomodir angkutan ojek sebagai angkutan umum seperti yang terjadi di beberapa Negara. Perlu direnungkan pendapat dari Eugene Ehrlich bahwa hukum positif akan efektif apabila selaras dengan hukum yang hidup dalam masyarakat (living law), atau apa yang disebut antropolog sebagai pola kebudayaan.

Menurut penulis seberat apapun sanksi bagi angkutan ojek, selama itu fungsional di tengah-tengah masyarakat, dan bersesuaian dengan living law, masih selama itu angkutan ojek akan eksis. Menurut Satjipto Rahardjo, hukum bukan raja (segalanya), tetapi sekadar alat bagi manusia untuk memberi rahmat kepada dunia dan kemanusiaan. Hukum tidak ada untuk dirinya sendiri, melainkan untuk sesuatu yang lebih luas dan lebih besar. Hukum untuk manusia, bukan manusia untuk hukum. Maka, setiap ada masalah dalam dan dengan hukum, hukumlah yang ditinjau serta diperbaiki, bukan manusia yang dipaksa untuk dimasukkan ke dalam skema hukum.

Perlu juga diperhatikan bahwa salah satu tujuan hukum adalah Pengayoman meliputi : 1. mewujudkan ketertiban dan keteraturan 2. mewujudkan kedamaian sejati 3. mewujudkan keadilan 4. mewujudkan kesejahteraan dan keadilan sosial warga masyarakat selama tidak melanggar hak dan merugikan orang lain tanpa rasa khawatir akan : a. secara bebas melakukan apa yang dianggap benar b. secara bebas dapat mengembangkan bakat dan minat c. secara bebas merasa selalu mendapat perlakuan wajar.

Jika Undang-Undang No. 22 Tahun 2009 tidak direvisi dan mengakomodir angkutan ojek sebagai angkutan umum seperti yang terjadi di beberapa Negara, maka tentunya ini berlawan dengan pengayoman yang menjadi tujuan dari hukum sendiri, dan juga mempertegas bahwa hukum itu bukan untuk manusia tapi hukum untuk dirinya sendiri, dan hukum itu berarti raja. Jika ini terjadi maka hukum akan selalu tertinggal dari perubahan sosial.

Dalam konteks ini penting diingat pendapat Soerjono Soekanto bahwa sistem hukum tidak mungkin sepenuhnya tertutup. Sistem yang tertutup secara mutlak akan menyulitkan dan menghalang-halangi penyesuaian kaidah-kaidah dalam hukum terhadap perubahan-perubahan yang terjadi dalam masyarakat, perubahan-perubahan tersebut oleh timbulnya kebutuhan-kebutuhan baru. Selain itu suatu sistem hukum tidak akan mungkin hidup lama apabila tidak mendapat dukungan sosial yang luas.

Hukum yang berlaku di Indonesia adalah hukum positif, maka di luar itu akan dikatakan ilegal. Sebagai aturan formal, undang-undang telah mengatur 
sedemikian rupa berkenaan dengan angkutan jalan, namun ojek tidak termuat di dalamnya. Fakta dilapangan memperlihatkan bagaimana masyarakat sangat membutuhkan ojek sebagai salah satu alternatif angkutan umum dengan segala keunggulan dan kelemahannya. Di sisi lain, undang-undang tidak mengatur soal ojek yang mengakibatkan ojek dikatakan sebagai angkutan umum ilegal. Tidak ditemui satupun klausul yang membolehkan ojek beroperasi sebagai angkutan umum. Dengan kata lain, keberadaan ojek dianggap telah melangkahi undangundang.

Pada hurufe Pasal 10 ayat (1) Undang-UndangNomor 12 Tahun 2011 tentang Pembentukan Peraturan perundang-Undangan, dikatakan materi muatan yang harus diatur dengan Undang-Undang berisi salah satunya pemenuhan kebutuhan hukum dalam masyarakat: (a) pengaturan lebih lanjut mengenai ketentuan Undang-Undang Dasar Negara Republik Indonesia Tahun 1945; (b) perintah suatu Undang-Undang untuk diatur dengan Undang-Undang; (c) pengesahan perjanjian internasional tertentu; (d) tindak lanjut atas putusan Mahkamah Konstitusi; dan/atau (e) pemenuhan kebutuhan hukum dalam masyarakat.

Memasukkan ojek ke dalam peraturan perundang-undangan berarti juga termasuk dalam pemenuhan kesejahteraan yang berbentuk perlindungan dan jaminan sosial. Ojek perlu diatur demi lebih terciptanya keamanan khususnya melihat potensi ojek yang sangat tinggi sebagai kebutuhan transportasi masyarakat khususnya di wilayah yang sulit dijangkau angkutan umum lainnya. Dari sisi tukang ojek, keamanan ditentukan dari kepedulian mereka menaati aturan lalu lintas. Seperti memakai helm, kelengkapan kaca spion, surat-surat lalu lintas, dan sebagainya. Dari sisi penumpang, selama ini urusan keselamatan masih sangat ditentukan dari kesadaran masing-masing. Hal lain yang perlu diperhatikan dari perlunya melegalkan status ojek, adalah dari faktor ketertiban masyarakat khususnya di lingkungan masyarakat berlalu lintas.

Melihat kebutuhan masyarakat akan angkutan ojek, menggerakkan beberapa pemerintah daerah untuk mengeluarkan peraturan daerah yang berkaitan dengan ojek sebagai bentuk perlindungan hukumnya, seperti Peraturaan Daerah Kota Palu Nomor 17 Tahun 2003 Tentang Izin Penyelenggaraan Sepeda Motor (Ojek), Peraturan Daerah Kabupaten Dompu Nomor 7 Tahun 2004 Tentang Petunjuk Pelaksanaan Izin Usaha Angkutan Penumpang Umum Dengan Kendaraan Bermotor Roda Dua/Ojek, Peraturan Daerah Kota Palopo Nomor 04 Tahun 2004 Tentang Retribusi Izin Sepeda Motor (Ojek) Sebagai Angkutan Alternatif Masyarakat, Peraturan Daerah Kabupaten Majene Nomor 12 Tahun 2004 Tentang Usaha Angkutan Dan Retribusi Izin Usaha Angkutan Khusus (Ojek). 
Pemerintah pusat hendaknya tidak malu untuk meniru langkah-langkah solutif beberapa pemerintah daerah yang telah mengeluarkan peraturan angkutan dengan sepeda motor di atas, sebagai payung hukum terhadap keberadaan angkutan orang dengan sepeda motor, bukan mempertahankan peraturan yang tidak memiliki basis sosial yang kuat di masyarat.

\section{Simpulan}

Berdasarkan pembahasan di atas, maka dapat disimpulkan:pertama, Motorcycle Taxi merupakan solusi angkutan yang mashlahah bagi kebutuhan tarnsportasi masyarakat luas. Kedua, Kebutuhan masyarakat terhadap Motorcycle Taxi yang masih terus proses menjadi, maka itu sudah cukup untuk dijadikan argumentasi bahwa perlindungan konsumen angkutan ojek sangat urgen untuk dilakukan dengan cara memberikan kepastian hukum legalitas angkutan ojek melalui revisi Undang-Undang No. 22 Tahun 2009, seperti yang terjadi dibeberapa Negara yang mengakomodir ojek sebagai angkutan umum.

\section{Daftar Pustaka}

\section{Buku}

Al-Buti, Muhammad Said Ramadan. Dawabit al-Maslahah $f i$ Shariá al-Islamiyyah. Beirut : Muassasah al-Risalah, 2001.

Al-Ghazali, Abu Hamid. Al-Mustasfa fi Ilmi al-Ushul, Juz 2. Madinah Munawwarah: Islamic University, 1992.

Al-Suyuthi, Jalal al-Din. Al-Ashbah wa Al-Nadzair. Beirut, Dar al-Fikr, tth.

Al-Syatibiy, Abu Ishaq. Al-Muwafaqat Fi Usul Al-Shariah. Beirut: Dar Al-Kutub Al-Arabi, 2002.

Cervero, Robert. Informal Transport in the Developing World. Nairobi: United Nations for Human Settlements, th.

Hadi, Soetrisno. Metodologi Reseacrh Jilid II. Yogyakarta: Yayasan Penerbit Fakultas Psikologi UGM, 1985.

Manzur, Ibn. Lisan al-A'Arabi. Cairo: Dar al-Hadith, 2003.

Muhammad, Abdul Kadir, Hukum Pengangkutan Niaga, Bandung: PT Citra Aditya Bakti, 2008. 
Narbuko, Cholid dan Abu Achmadi. Metodologi Penelitian. Jakarta: Bumi Aksara, 2005.

Rasjidi, Lili dan I.B Wysa Putra. Hukum Sebagai Suatu Sistem. Bandung: Remaja Rosdakarya, 1993.

Soekanto, Soerjono dan Sri Mamudji. Penelitian Hukum Normatif Suatu Tinjauan Singkat, ed. Kesembilan. Jakarta: PT.Raja Grafindo Persada, 2006.

Soekanto, Soerjono. Pokok-Pokok Sosiologi Hukum. Jakarta: Rajawali Pers, 2014. Soerjono, Soekanto. Pengantar Penelitian Hukum. Jakarta: Universitas Indonesia Press, 1986.

\section{Artikel}

Anwar. Analisa Kinerja Ojek. Jurnal Sains dan Inovasi. Vol. 5 No.2 Tahun 2009.

Edi. S, Agus Sarwo. Karakter Pengoperasian Angkutan Ojek Sebagai Sarana Angkutan di Kota Gubug. Skripsi tidak diterbitkan. Semarang: Universitas Diponegoro, 2005.

Kalo, Syafruddin, Penegakan Hukum Yang Menjamin Kepastian Hukum Dan Rasa Keadilan Masyarakat Suatu Sumbangan Pemikiran. Makalah disampaikan pada "Pengukuhan Pengurus Tapak Indonesia Koordinator Daerah Sumatera Utara”, pada hari Jum'at, 27 April 2007, Gayo Room Garuda Plaza Hotel, Jl. Sisingamangaraja No. 18 Medan.

Noer, Zaini \& Usman Melayu, Kebijakan Transportasi, Simposium III FSTPT, Jakarta, 2000.

Oshima, Ryosuke, dkk. Study on Regulation of Motorcycle Taxi Service in Bangkok. Journal of the Eastern Asia Society for Transportation Studies. Vol. 7 Tahun 2007.

Pangkerego, Olga A. dan Friend H. Anis. Aspek Hukum Pelrindungan Konsumen Terhadap Jasa Transportasi Online Menurut Undnag-Undang No. 8 Tahun 1999 tentang Pelrindungan Konsumen. Jurnal Lex Privatum. Vol. VI No. 3 Tahun 2018.

Pattinama, Marcus J. Pengentasan Kemiskinan dengan Kearifan local (Studi Kasus di Pulau Buru-Maluku dan Surade Jawa Barat. Makara, Sosial 
Humaniora. Vol. 13 No. 1 Tahun 2009.

Pratama, Geistiar Yoga dan Suradi Aminah. Perlindungan Hukum Terhadap

Data Pribadi Pengguna Jasa Transportasi Online Dari Tindakan

Penyalahgunaan Pihak Penyedia Jasa Berdasarkan Undnag-Undang No. 8

Tahun 1999 tentang Perlindungan Konsumen. Diponegoro Law Journal. Vol.

5 No. 3 Tahun 2016.

Setijowarno, Djoko dan Yovita Indrayati. Peningkatan Peran Ojek sebagai Salah

Satu Alternatif Angkutan. Referensi Ilmiah Indonesia, 2010.

Shantyabudi, Firman. Tukang Ojek dan Interaksi Sosial. Skripsi tidak diterbitkan. Jakarta: Universitas Indonesia, 2003.

Suwandono, Agus. Pendekatan Holistik Transportasi berbasis Aplikasi Dalam Kerangka Hukum Perlindungan Konsumen. Jurnal Mimbar Hukum. Vol. 31 No. 1 Tahun 2019.

\section{Peraturan Perundang-undangan}

Kitab Undang-Undang Hukum Perdata.

Undang-Undang No. 22 tahun 2009 tentang Lalu Lintas dan Angkutan Jalan.

Undang-Undang No. 8 Tahun 1999 tentang Perlindungan Konsumen.

Undang-Undang Nomor 12 Tahun 2011 tentang Pembentukan Peraturan perundang-Undangan.

Peraturan Pemerintah No. 12 Tahun 2019 tentang Perlindungan Keselamatan Pengguna Sepeda Motor yang Digunakan untuk kepentingan Masyarakat.

Peraturaan Daerah Kota Palu Nomor 17 Tahun 2003 Tentang Izin Penyelenggaraan Sepeda Motor (Ojek).

Peraturan Daerah Kabupaten Dompu Nomor : 7 Tahun 2004 Tentang Petunjuk Pelaksanaan Izin Usaha Angkutan Penumpang Umum Dengan Kendaraan Bermotor Roda Dua/Ojek.

Peraturan Daerah Kota Palopo Nomor : 04 Tahun 2004 Tentang Retribusi Izin Sepeda Motor (Ojek) Sebagai Angkutan Alternatif Masyarakat.

Peraturan Daerah Kabupaten Majene Nomor 12 Tahun 2004 Tentang Usaha Angkutan Dan Retribusi Izin Usaha Angkutan Khusus (Ojek). 